\title{
Rancang Bangun Mesin Pencetak Pellet dari Limbah Telur Solusi Pakan Ternak Alternatif
}

\author{
Setiya Nugroho'), Irwan Setyowidodo ${ }^{2)}$, Hesti Istiqlaliyah ${ }^{3)}$ \\ ${ }^{1), 2), 3)}$ Program Studi Teknik Mesin, Univ. Nusantara PGRI Kediri \\ E-mail: ${ }^{1)}$ Suwito.unpkediri@gmailcom, ${ }^{2)}$ Irwansetyo@ unpkediri.ac.id, ${ }^{3)}$ \\ Hesti.isti@gmail.com
}

\begin{abstract}
Abstrak
Perancangan ini dilatar belakangi hasil observasi dan studi literatur, tepatnya didaerah Kalidawir limbah penetasan telur bebek cukup besar. Hampir setiap hari limbah tersebut ada, akan tetapi masih belum banyak dimanfaatkan secara optimal oleh peternak maupun masyarakat sekitar. Khususnya sebagai pakan ternak alternatif, karena belum adanya penggunaan mesin pencetak pelet dari bahan limbah telur penetasan bebek. Biasanya mesin ini hanya digunakan dalam pencetakan pelet dari bahan dedak halus dan frementasi yang telah dirancang khusus untuk membuat pakan ternak. Perancangan ini dilakukan untuk untuk memebuat alat pencetak pellet dari limbah telur bebek beserta menghitung kapasitas produksinya. Hasil perancangan menggunakan motor listrik $1400 \mathrm{rpm}$, gear box 1:60, tanki conveyor dengan panjang $220 \mathrm{~mm}$, die dengan ukuran 2 dan $4 \mathrm{~mm}$ dan tebal $8 \mathrm{~mm}$, pisau pemotong dengan tebal $1 \mathrm{~mm}$, panjang $35 \mathrm{~mm}$ dengan kecepatan $9 \mathrm{rpm}$ dan menghasiilkan kapasitas 15 kg/jam.
\end{abstract}

Kata Kunci: Limbah Telur Bebek, Pisau Pemotong, Mesin Pencetak Pelet.

\section{Abstract}

This design is based on the results of observations and literature studies, to be exact in Kalidawir, the duck egg hatching waste is quite large. Almost every day the waste is there, but it is still not widely used optimally by farmers and the surrounding community. Especially as an alternative animal feed, because there is no use of a pellet printing machine from duck hatching egg waste material. Usually this machine is only used in printing pellets from fine bran and frementation materials that have been specifically designed to make animal feed. The design is done to make pellet molding equipment from duck egg waste and calculate its production capacity. The results of the design using an electric motor $1400 \mathrm{rpm}, 1: 60$ gear box, conveyor tank with a length of $220 \mathrm{~mm}$, die with size 2 and $4 \mathrm{~mm}$ and thickness of $8 \mathrm{~mm}$, cutting blade with a thickness of $1 \mathrm{~mm}$, length of $35 \mathrm{~mm}$ at a speed of 9 rpm and produce capacity $15 \mathrm{~kg} / \mathrm{hour}$.

Keywords: Duck Egg Waste, Cutting Knife, Pellet Making Machine. 


\section{PENDAHULUAN}

Perkembangan teknologi telah banyak membantu umat manusia dalam memudahkan suatu pekerjaan Mesin pembuat pellet adalah sebuah alat yang dirancang khusus untuk membuat pakan ternak[1]. Mesin pembuat pelet memiliki efisiensi yang tinggi dengan menggunakan prinsip kerja screw conveyor yang memanfaatkan ulir-ulir pada screw sebagai wadah yang membawa bahan dan menekannya (pressing) kearah ujung tabung (form hole plate) yang telah dirancang sedemikian rupa yang akan menjadikan bahan berbentuk pelet padat (kompak).

Limbah telur merupakan limbah yang paling banyak dibuang oleh pengusaha penetasan telur karena telur tersebut sudah dianggap salah satu produk gagal. Limbah penetasan mempunyai kandungan nutrien yang cukup baik serta dapat digunakan sebagai sumber protein, energi dan kalsium. Penggunaan limbah penetasan telur lebih murah dan menguntungkan dibandingkan tepung kedelai dan tepung ikan. Salah satu usaha yang dilakukan untuk menghemat biaya produksi ini adalah dengan merancang alat produksi yang mampu menghasilkan produk pakan pelet. Berdasarkan penelitian Budi dkk. bahwa pemberian tepung cangkang telur dalam ransum berpengaruh nyata terhadap tingkat fertilitas pada burung puyuh[2]. Hasil penelitian Santoso dilaporkan bahwa tepung dari limbah penetasan cukup baik pengaruhnya terhadap pertumbuhan babi[3]. Penelitian yang dilakukan oleh Aria Triwissaka, dkk dengan judul Rancang Bangun Mesin Pelet Pakan Ikan Dengan Mekanisme "Screw Press" Dari Bahan Baku Yang Telah Diproses Fermentasi didapatkan pelet dari limbah dengan geometri pelet sebesar $4 \mathrm{~mm}$ dari lingkaran luar, dengan gaya torsi memutar screw pres sebesar 5608,32 $\mathrm{kgf} / \mathrm{mm}$ dan kapasitas yang diuji sebesar $1,3 \mathrm{~kg} / \mathrm{jam}[4]$. Silvia Uslianti, dkk juga telah membuat mesin pellet untuk membantu Kelompok Usaha Tambak Ikan dalam mengatasi permasalahan mahalnya harga pakan ikan[5].

. Pada proses pengolahan pellet ini diperlukan satu alat pencetak yang digunakan untuk memproduksi atau membentuk suatu adonan untuk dijadikan makanan ternak berbentuk pellet dengan ukuran yang sudah ditentukan. Mesin pencetak pellet sangat bagus dan efisien untuk 
memproduksi pakan ternak dalam bentuk silinder. Alat pencetak pelet yang berbentuk silinder, pada bagian dalamnya terdapat ulir pengepres pelet. Ulir pengepres ini mendorong bahan adonan ke arah ujung silinder dan menekanan plat berlubang sebagai pencetak pelet. Lubang plat menggerakan poros pencetak sesuai dengan ukuran pelet yang di kehendaki, setelah itu akan terpotong oleh pisau pemotong[6].

\section{METODE PENELITIAN}

Dalam perancangan ini, metode yang digunakan adalah Target Oriented Planning dan melakukan eksperimen dengan pengolahan kembali limbah telur menjadi pellet. Target Oriented Planing adalah titik tolak pemikiran yang lebih ditekankan semata-mata pada tujuan dan sasaran yang akan dicapai pada masa mendatang. Dalam pendekatan ini suatu target ideal yang ingin dicapai di masa mendatang merupakan faktor penentu yang sangat penting. Target didasarkan pada keadaan masa kini untuk meningkatkan kondisi sekarang menjadi ke kondisi lebih baik dimasa mendatang.

Prosedur perancangan ini merupakan langkah-langkah prosedur yang ditempatkan oleh pengembang untuk membuat produksi yang sepesifik. Perancangan ini bertujuan untuk meneliti ulang pengembangan alat dan kualitas yang dihasilkan. Fase dalam proses perancangan berbeda satu dengan lainnya. Fase-fase proses perancangan tersebut dapat dilihat dalam diagram alir 


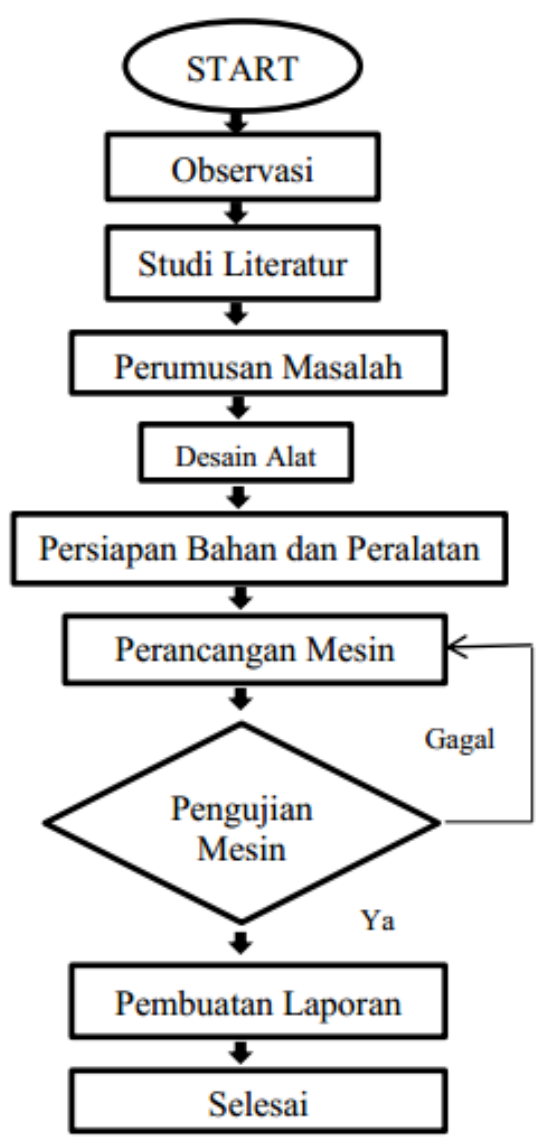

Gambar 1. Diagram alir proses penelitian

Dalam pelaksanaan perancangan prosedur yang dilakukan yaitu:

a. Observasi Lapangan

Dalam observasi lapangan akan melakukan peninjauan yang meliputi observasi mesinmesin pembuat pelet yang sudah ada mulai dari penggununaan secara manaual sampai dengan penggunaan motor dan disel. Observasi yang dilakukan meliputi mekanisme, bahan baku dan material yang digunakan serta penggunaan mesin. Tujuan dari observasi ini sendiri adalah agar dapat mengetahui secara nyata proses dari sistem kerjanya.

b. Studi literatur

Dalam perancangan mesin pencetak pelet ini mencari studi literatur yang mempelajari tentang mekanisme pembuatan mesin melalui buku-buku berbagai sumber maupun media internet. Guna untuk mengetahui prinsip mekanisme alat dengan masalah perancangan.

c. Perumusan masalah

Setelah melakukan studi literatur terhadap observasi lapangan ditemukan Rancang Bangun Mesin Pencetak Pellet dari Limbah Telur Solusi Pakan Ternak Alternatif (Setiya Nugroho, Irwan Setyowidodo, Hesti Istiqlaliyah) 
permasalahan mengenai mesin pembuat pelet dengan mekanisme yang terdahulu.

d. Desain alat

Membuat desain alat yang diperlukan dalam proses pembuatan. Perancangan gambar dilakukan setelah melakukan observasi lapangan, studi literatur dan menentukan masalah. Desain yang akan dibuat meliputi kerangka, mesin pelet keseluruan, sistem penggerak.

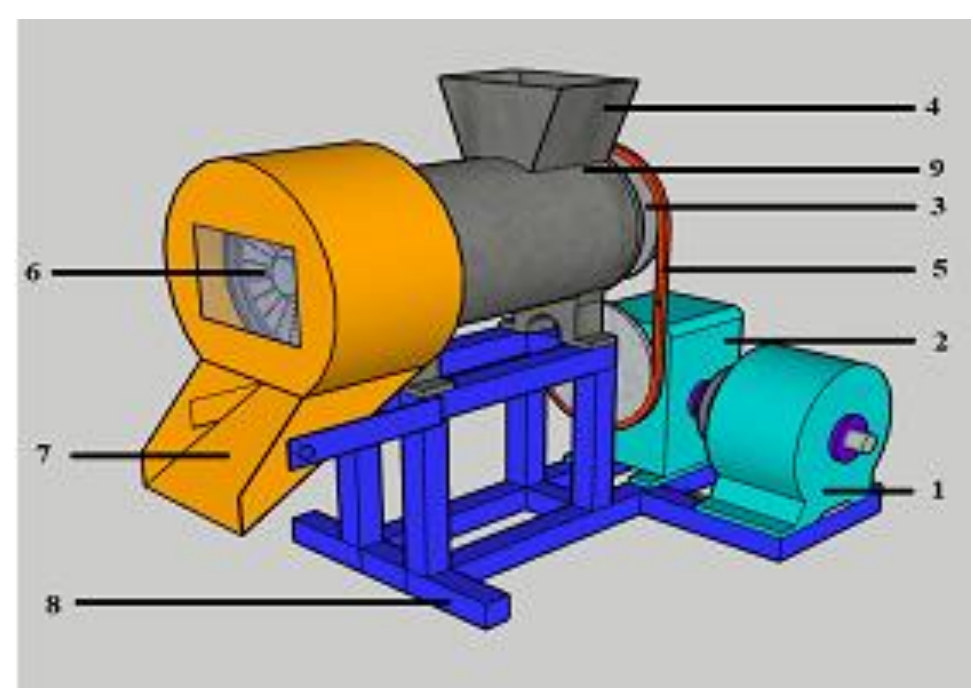

Gambar 2. Desain alat

Keterangan desain mesin pencetak pelet.

1. Motor Listrik,

2. Gear Box,

3. Gear,

4. Hopper,

5. Rantai,

6. Saluran pencetak pellet,

7. Hopper,

8. Kerangka Mesin,

9. Silinder,

10. Screw Conveyor.

e. Persiapan bahan dan Peralatan.

Bahan-bahan yang digunakan dalam perancangan dan pembuatan adonan :Plat besi, Plat stenlis, Elektroda, Besi siku, Cat, Plat berlubang, Baut dan Mur, 
Besi hollow, Limbah telur yang sudah dihaluskan, Tepung Kanji, Vitamin, Air, Bekatul, Kebi. Alat-alat yang digunakan dalam perancangan atau dalam proses pengerjaan dan dalam proses pengujian adalah : Las listrik, Mesin gerinda, Mesin bor, Kunci pas, Tang, Pahat, Palu, Penggaris, Jangka, Timbangan bahan, Stopwatch, Ember plastik, Alat tulis menulis, Timbangan bahan.

\section{f. Perancangan mesin}

Setelah pendesainnan mesin sudah digambar maka dilanjutkan proses perancangan mesin alat pembuat pakan ternak berupa pellet. Rancangan alat menggunakan mekanisme alat pencetak pakan ternak berbentuk gilingan daging dan menggunakan bahan baku dari limbah telur yang sudah diproses untuk dijadikan bentuk pellet. Dalam perancangan penggerak yang digunakan yaitu motor listrik 1,5 hp dan menggunakan 2 desain mata pisau dan die (cetakan) yang berbeda.

\section{g. Pengujian mesin}

Setelah proses perancangan mesin jadi tahap selanjutnya yaitu proses pengujian mesin. Dalam proses ini parameter yang diamati yaitu kapasitas daya tampung alat (kg/jam). Pengukuran kapasitas daya tampung alat dilakukan dengan membagi berat pelet yang terbentuk terhadap waktu yang dibutuhkan untuk membentuk pakan ternak bentuk pelet.

Kapasitas pencetakan $(\mathrm{kg} / \mathrm{jam})=\frac{\text { berat pelet terbentuk }}{\text { waktu yang dibutuhkan }}$

Persen yang tidak tercetak $=\frac{\text { Berat awal }- \text { berat akhir }}{\text { berat awal }} \times 100 \%$

\section{HASIL DAN PEMBAHASAN}

Beberapa data komponen dan bahan dibawah ini yang digunakan untuk mendukung terwujudnya perancangan alat pencetak pellet dari penetasan limbah telur bebek.

Tabel 1. Spesifikasi alat

\begin{tabular}{|c|c|c|}
\hline No & Nama komponen dan bahan yang dipakai & Spesifikasi \\
\hline 1 & Tanki Screw Conveyor & Panjang $25 \mathrm{~cm}$ \\
\hline 2 & Motor listrik & Putaran $1400 \mathrm{rpm}$ \\
\hline
\end{tabular}

Rancang Bangun Mesin Pencetak Pellet dari Limbah Telur Solusi Pakan Ternak Alternatif (Setiya Nugroho, Irwan Setyowidodo, Hesti Istiqlaliyah) 


\begin{tabular}{|c|c|c|}
\hline 3 & Gear box & $1: 60$ \\
\hline 4 & Gear & 12,32 gigi \\
\hline 5 & Rantai & Rantai motor \\
\hline 6 & Plat stanlis $1 \mathrm{~mm}$ & $10 \mathrm{~cm} \times 10 \mathrm{~cm}$ \\
\hline 7 & Plat besi $4 \mathrm{~mm}$ & $14 \mathrm{~cm} \mathrm{x} 14 \mathrm{~cm}$ \\
\hline 8 & Plat stanlis $3 \mathrm{~mm}$ & $26 \mathrm{~cm} \times 18 \mathrm{~cm}$ \\
\hline 9 & Besi hollow & $1 \mathrm{ebar} 4 \mathrm{~cm}$ \\
\hline 10 & Plat Besi $6 \mathrm{~mm}$ & $20 \times 20 \mathrm{~cm}$ \\
\hline
\end{tabular}

Keterangan :

1) Plat stanlis $1 \mathrm{~mm}$ digunakan dalam pembuatan jenis pisau.

2) Plat besi $4 \mathrm{~mm}$ digunakan sebagai tempat dudukan gilingan daging.

3) Plat stanlis $2 \mathrm{~mm}$ digunakan dalam pembuatan hopper.

4) Besi hollow digunakan dalam pembuatan kerangka.

5) Plat besi $6 \mathrm{~mm}$ digunakan dalam pembuatan die.

a. Perhitungan Daya Motor dan Pemilihan Motor

Pada mesin yang sudah ada di luar didapatkan kecepatan putar mesin sebesar 600 Rpm, 1400 Rpm, 1440 Rpm. Jika kecepatan putar mesin pencetak pelet dari limbah telur direncanakan $1400 \mathrm{Rpm}$, maka daya yang dibutuhkan dengan besar torsi yang direncanakan sebesar $77 \mathrm{~kg} \mathrm{~cm}$. Sehingga dapat dihitung dengan persamaan berikut :

$\mathrm{P}(\mathrm{HP})=\frac{T(l b f . f t) \times n(R p m)}{5250}$

Dimana :

$\mathrm{P}=$ Daya $(\mathrm{HP})$

$\mathrm{n}=$ Kecepatan Putar $(\mathrm{Rpm})$

$\mathrm{T}=$ Torsi (lbf.ft)

Jika : $1 \mathrm{~kg} \mathrm{~cm}=0,0723301 \mathrm{lb}-\mathrm{ft}$

$77 \mathrm{~kg} . \mathrm{cm}=77 \mathrm{kgcm} \times 2,20462262185 \mathrm{lb} / \mathrm{kg} \times 0,032808399 \mathrm{ft} / \mathrm{cm}=5,569 \mathrm{lb}-\mathrm{ft}$

Maka : P $(\mathrm{HP})=\frac{T(l b f . f t) \times n(R p m)}{5250}=\frac{5,569(l b f . f t) \times 1400(R p m)}{5250}=1,48 \mathrm{HP} \approx 1,5 \mathrm{HP}$

b. Perhitungan gaya yang bekerja pada poros 
Dimana diketahui daya motor sebesar $1,5 \mathrm{Hp}$, putaran poros $1400 \mathrm{rpm}$ dan faktor koreksi yang digunakan adalah $\mathrm{fc}=1$, sehingga dapat dihitung dengan menggunakan persamaan daya motor $(\mathrm{P})$

$$
\begin{aligned}
\mathrm{P} & =1,5 \mathrm{Hp}=1,5 \times 0,746=1,119 \mathrm{kw} \\
\mathrm{P}_{\mathrm{d}} & =\text { fc } \times \mathrm{P} \\
& =1 \times 1,119 \\
& =1,119 \mathrm{Kw}
\end{aligned}
$$

Momen puntir rencana, dihitung

$$
\begin{aligned}
\mathrm{T} & =9,74 \times 10^{5} \times \frac{P_{d}}{n} \\
& =9,74 \times 10^{5} \times \frac{1,119}{1400} \\
& =778,50 \mathrm{~kg} . \mathrm{mm}
\end{aligned}
$$

c. Perhitungan jumlah putaran yang dihasilkan

Dimana diketahui kecepatan putar awal mesin pencetak pelet ini sebesar 1400 Rpm dan ratio dari gear box $1: 60$ sehingga dapat dihitung dengan menggunakan rumus jumlah putaran yang dihasilkan, dihitung

$$
\begin{aligned}
N_{2} & =N_{1}: \text { Ratio } \\
& =1400: 60 \\
& =23,3 \mathrm{Rpm}
\end{aligned}
$$

\section{d. Perhitungan reduksi sproket dan rantai}

Agar putaran reduksi gear-box sesuai dengan perancangan yang dibutuhkan, perlu direduksi lagi dengan sproket dan rantai dengan ukuran perbandingan teeth output gearbox $=\mathrm{T} 12$ sedangkan teeth input mixer $=\mathrm{T} 32$.

Rumus : $N=\frac{N_{2}}{i}$

Keterangan :

$\mathrm{N}=$ reduksi sproket

$\mathrm{i} \quad=$ rasio sproket

$N_{2}=$ reduksi dari gear box

$N_{3}=$ reduksi mixer

Diketahui :

Rancang Bangun Mesin Pencetak Pellet dari Limbah Telur Solusi Pakan Ternak Alternatif (Setiya Nugroho, Irwan Setyowidodo, Hesti Istiqlaliyah) 
Rasio sprocket $=\mathrm{T} 12: \mathrm{T} 32$

$$
=1: 2,6
$$

Maka :

$N=\frac{N_{2}}{i}=\frac{23,3}{2,6}=9 \mathrm{Rpm}$

Rasio = Output Mixer T32: Input Pencetak Pelet T32

$$
=1: 1
$$

Maka :

$N=\frac{N_{3}}{i}=\frac{9}{1}=9 \mathrm{Rpm}$

e. Uji kinerja alat pencetak pellet

Hasil dari uji kinerja dilakukan sebanyak 3 kali pengulangan dengan berat bahan baku yang digunakan sebanyak $7 \mathrm{~kg}$, Perhitungan kapasitas pencetakan dihitung dengan menggunakan perhitungan :

1) $\frac{\text { Berat pelet terbentuk }(\mathrm{kg})}{\text { Waktu yang dibutuhkan(jam) }}=\frac{6,2}{0,413}=15,01 \mathrm{~kg} / \mathrm{jam}$

2) $\frac{\text { Berat pelet terbentuk }(\mathrm{kg})}{\text { Waktu yang dibutuhkan(jam) }}=\frac{6,3}{0,411}=15,32 \mathrm{~kg} / \mathrm{jam}$

3) $\frac{\text { Berat pelet terbentuk }(\mathrm{kg})}{\text { Waktu yang dibutuhkan(jam) }}=\frac{6,4}{0,410}=15,60 \mathrm{~kg} / \mathrm{jam}$

Perhitungan persen yang tidak tercetak dihitung dengan menggunakan persamaan perhitungan sebagai berikut:

1) $\frac{\text { Berat awal-Berat akhir }}{\text { berat awal }} \times 100 \%=\frac{7-6,2}{7} \times 100 \%=11,42 \%$

2) $\frac{\text { Berat awal-Berat akhir }}{\text { berat awal }} \times 100 \%=\frac{7-6,3}{7} \times 100 \%=10 \%$

3) $\frac{\text { Berat awal-Berat akhir }}{\text { berat awal }} \times 100 \%=\frac{7-6,4}{7} \times 100 \%=8,57 \%$

Berdasarkan hasil pengujian kinerja mesin sebanyak 3 kali. menerangkan bahwa kapasaitas yang dihasilkan sebesar 15,32 kg/jam.

\section{KESIMPULAN}

Dari perancangan mekanisme mesin pencetak pelet dari bahan baku limbah telur diperoleh kesimpulan sebagai berikut:

a. Komponen untuk membangun mesin pencetak pelet adalah dengan menggunakan rangka dari plat besi dengan ketebalan $6 \mathrm{~mm}$ dan dimensi $\mathrm{p}$ 
x t x $1=140 \mathrm{~mm}$ x $170 \mathrm{~mm}$ x $140 \mathrm{~mm}$, Unit penggerak motor listrik dengan daya 1,5 HP dan untuk putaran $1400 \mathrm{Rpm}$, Untuk pisau pemotong bahan terbuat dari stainlis dengan panjang $30 \mathrm{~mm}$ dan tebal 1 $\mathrm{mm}$, die (cetakan) berdiameter $2 \mathrm{~mm}$ dan $4 \mathrm{~mm}$ bahan terbuat dari plat besi dengan tebal $6 \mathrm{~mm}$.

b. Untuk mengetahui kapasitas yang tercetak yaitu dengan cara membagi berat pelet yang terbentuk dengan waktu yang dibutuhkan. Hasil dari uji kinerja mesin yaitu :

1) Kapasitas yang tercetak $=15,31 \mathrm{~kg} / \mathrm{jam}$

2) Kapasitas yang tidak tercetak $=9,9 \%$

\section{DAFTAR PUSTAKA}

[1] Zikri. Rancang Bangun Mesin Pembuat Pelet Untuk Pakan Ternak. Tugas Akhir tidak diterbitkan. Padang: Politeknik Universitas Andalas. 2008.

[2] Jamila. Pemanfaatan Limbah Cangkang Telur. Modul https://www.scribd.com/document/357025518/Modul-

1PemanfaatanCangkang-Telur pdf. Diakses pada tanggal 13 Mei 2018. 2014.

[3] Jamila. Pemanfaatan Limbah Cangkang Telur. Modul https://www.scribd.com/document/357025518/Modul-

1PemanfaatanCangkang-Telur pdf. Diakses pada tanggal 13 Mei 2018. 2014.

[4] Aria Triwissaka, dkk. Teknologi Pengolahan Limbah Dan Sisa Hasil Ternak. Tugas Akhir tidak diterbitkan. Surabaya: Institut Teknologi Sepuluh Nopember. 2014

[5] Uslianti Silvia, dkk. Rancang Bangun Mesin Pelet Ikan Untuk Kelompok Usaha Tambak Ikan. Universitas Tanjungpura. Jurnal.untan.ac.id/index.php/Elkha/ article/view/9129 diakses pada tanggal 13 Mei 2018. 2014.

[6] Satriyo BA, dkk. Balai Besar Pengembangan Mekanisasi Pertanian Situgadung. Legok.Tangerang. http://www.cabi.net.id. Diakses pada tanggl 21 Mei 2018. 2008.

Rancang Bangun Mesin Pencetak Pellet dari Limbah Telur Solusi Pakan Ternak Alternatif (Setiya Nugroho, Irwan Setyowidodo, Hesti Istiqlaliyah) 